\title{
An Exploration of Teachers' Skills, Perceptions and Practices of ICT in Teaching and Learning in the Ghanaian Second-Cycle Schools
}

\author{
Charles Buabeng-Andoh \\ Pentecost University College, Ghana
}

\begin{abstract}
This study was conducted to explore teachers' skills, perceptions, and practices about ICT in second-cycle institutions in Ghana. Questionnaires were distributed to 273 teachers in different departments, 241 were returned, and 231 were valid for data analysis, representing a response rate of $85 \%$. The validity of the questionnaire was approved by a panel of experts in the field. The Cronbach's alpha reliability coefficient was 0.91 . Descriptive statistics and correlation were used to analyze data. Of the 231 teachers, $66 \%$ were males and $34 \%$ were females. Majority of the respondents were between the ages 30-39. The correlation analysis revealed positive correlation between ICT use and teachers' competences. Further, teachers' perceptions in terms of using ICT were found to be positive but not statistically significant. Finally, the study revealed inverse correlations among ICT use, age, and teaching experience. The descriptive results indicated that teachers' knowledge in basic ICT applications as well as integrating ICT into teaching and learning processes was low. These results provide evidence that the introduction of ICT in teaching and learning has not brought any change in the delivery of education in second-cycle schools in Ghana. This also implies that teachers have not shifted from teacher-centered instruction to student-centered learning. From the findings of the study, it is recommended that courses such as computer supported learning, ICTs and designing instructional materials should be introduced in initial teacher training programs to improve teachers' level of confidence and perceptions towards the use of ICT.
\end{abstract}

Keywords: Technology integration in schools; Teachers' perceptions of ICT; Student-centered learning, Information and communication technologies; Teacher education

\section{Introduction}

The rapid growth in Information Communication and Technologies (ICT) have brought remarkable changes in the twenty-first century and affected demands of the modern society. ICT is becoming increasingly important in our daily lives as well as in educational systems. Therefore, there is a growing demand on educational institutions to use ICT to teach the skills and knowledge that students need for the $21^{\text {st }}$ century. Realizing the effect of ICT on the workplace and everyday life, today's educational institutions try to restructure their educational curricula and classroom facilities in order to bridge the existing technology gap in teaching and learning processes. This restructuring requires effective adoption of technologies into existing learning environments in 
order to provide learners with knowledge of specific subject areas, to promote meaningful learning and to enhance professional productivity.

Education has immensely contributed to an increase in developing knowledge, providing an enabling environment for innovation and in building human capital required for a potential knowledge economy. Global developments in education and challenging ICT demands have made a remarkable shift in the structure of the enabling ICT environment and the utilization of ICT technologies in education. Such technologies have become the key force of the digital network in an era of technology-driven education. More schools and communities now have access to ICT resources to join the global economy with knowledge workers who have 21st century skills and are inspired by life-long learning.

ICTs have great potential for knowledge dissemination, effective learning, and the development of more efficient educational services. Moreover, the adoption of ICT by education has been seen as a powerful way to contribute to educational change, better prepare students for the information age, improve learning outcomes and competencies of learners, and equip students with survival skills for the information society. Therefore, teachers are expected to integrate ICT into their teaching and learning processes.

To successfully initiate and implement educational technology in the school program depends strongly on the teachers' support and attitudes. It is believed that if teachers perceived technology programs as neither fulfilling their own needs nor their students' needs, it is likely that they will not integrate the technology into teaching and learning. Evidence suggests that teachers' attitudes and beliefs influence successful integration of ICT into teaching (Hew \& Brush, 2007; Keengwe \& Onchwari, 2008). If teachers' attitudes are positive toward the use of educational technology, then they can easily provide useful insight about the adoption and integration of ICT into teaching and learning processes.

Some researchers studied the relationship between teachers' perceptions of the use of ICT and their actual integration of ICT into teaching and learning processes. Eugene (2006) explored the effect of teachers' beliefs and attitudes towards the use of ICT in classrooms. An observation method was used to collect data on teachers' beliefs and attitudes. The study revealed that there was inconsistency between teachers' beliefs and their actual use of technology in the classroom. Teachers' beliefs and teaching practices were found not to match. Similarly, Simonson (2004) used a quantitative study to explore the beliefs of primary school teachers on the use of ICT in teaching. The result revealed that teachers' beliefs and attitudes were related to their use of technology. Also, Drent and Meelissen (2008) conducted a study about factors which influence the innovative use of ICT by teacher educators in the Netherlands. A sample of 210 teachers was used for the study. Their study revealed that student-oriented pedagogical approach, positive attitude towards computers, computer experience, and personal entrepreneurship of the teacher educator have a direct positive influence on the innovative use of ICT by the teacher.

Research has shown that teachers' attitudes towards technology influence their acceptance of the usefulness of technology and its integration into teaching (Huang \& Liaw, 2005). In EU Schoolnet (2010) survey on teachers' use of Acer netbooks involving six European Union countries, a large 
number of participants believed that the use of netbook had positive impact on their learning, promoted individualized learning and helped to lengthen study beyond school day. However, evidence suggests that small number of teachers believe that the benefits of ICT are not clearly seen. The empirical survey revealed that one fifth of European teachers believed that the use of ICT in teaching did not benefit their students' learning (Korte \& Husing, 2007). A survey of UK teachers also revealed that teachers' positivity about the possible contributions of ICT was moderated as they became 'rather more ambivalent and sometimes doubtful' about 'specific, current advantages' (Becta, 2008, p.45).

Teachers' computer experience relates positively to their computer attitudes. The more experience teachers have with computers, the more likely that they will show positive attitudes towards computers (Rozell \& Gardner, 1999). Positive computer attitudes are expected to foster computer integration in the classroom (van Braak, Tondeur, \& Valcke, 2004). According to Woodrow (1992) for successful transformation in educational practice, user needs to develop positive attitudes toward the innovation.

Further, Teo (2008) conducted a survey on pre-service teachers' attitudes towards computer use in Singapore. A sample of 139 pre-service teachers was assessed for their computer attitudes using questionnaire with four factors: affect (liking), perceived usefulness, perceived control, and behavioral intention to use the computer. He found that teachers were more positive about their attitude towards computers and intention to use computer than their perceptions of the usefulness of the computer and their control of the computer.

However, while there are a number of studies on teachers' perceptions, skills and practices of ICT in secondary schools in developed countries, there is lack of study on teachers' perceptions, skills and uses of ICTs in second-cycle institutions in Ghanaian schools. This is the rationale for carrying out the present study. The current study used quantitative method to collect data and the research was guided by the following questions:

(1) What are teachers' perceptions of the application of ICT in teaching?

(2) What are teachers' perceived skills in ICT?

(3) What is the extent of teachers' integration of ICT into teaching and learning processes?

(4) What is the relationship between teachers' actual use of ICT and their computer perceptions, computer competence and demographics (such as age, teaching experience and computer experience)?

\section{Methodology}

\section{Participants}

The study was conducted in public second-cycle institutions. Two hundred and thirty-one teachers were selected from fourteen schools participated in the study. The sample size was made up of 153 males and 78 females. The ages of the participants ranged between 20 and 60 (mean = 25.9; 
standard deviation $=.927)$. The participating teachers were from different departments of the attending schools.

\section{Data Collection Methods}

A simple random sampling technique was used to select the teachers in second-cycle institutions who participated in this study. Questionnaires were delivered personally to assistant headteachers of each school for distribution to the participants. This method was chosen to avoid low response rate. Also, the involvement of teachers in the study was strictly voluntary. They were also assured of confidentiality of any information given. The questionnaire was pilot-tested to measure the reliability and to determine whether it was understandable for the target population. The validity was improved by consulting experts in the field. The final version of the questionnaire was sent to teachers. It was distributed to 273 teachers in different departments. One week was given to the teachers to complete the questionnaire except teachers in a particular school who were given two weeks to complete since they were busily invigilating end of term examinations. Follow-up phone calls were made to the assistant headteacher for academic affairs in each school to remind the teachers to complete the questionnaire. The questionnaires were collected in person from assistant heads. A total of 241 questionnaires were collected back from the participants indicating an $88 \%$ return rate. Of 241 questionnaires received, 10 were not used for data analysis since they were incomplete. Thus 231questionnaires were used for data analysis indicating an $85 \%$ valid response rate.

\section{Instrument}

A survey was designed to collect data from teachers in second-cycle institutions. The first section of the final version of the questionnaire focused on demographic information of the teachers based on gender, age, teaching experience, computer experience, and frequency of computer use. The second section consisted of Likert-type questions. The teachers were asked to rate their knowledge and skills in the use of ICT. Also, respondents were asked to rate the extent to which they integrated ICT into teaching to achieve professional objectives. Finally, teachers were asked to indicate the factors which affected their use of ICT in teaching. A reliability test was carried out to determine the internal consistency of items in the questionnaire by using Cronbach's Alpha reliability test. Cronbach's alpha coefficient was 0.903 . According to Kline (2005), alpha value of .90 is considered excellent, .80 very good, and .70 acceptable. In this study, the observed variables had good internal consistency.

\section{Data Analyses}

Data were analyzed using descriptive statistics. The researcher uses descriptive statistical technique to calculate the frequencies, means and standard deviations of the collected data. Descriptive statistics were used to answer the first three research questions and correlation analysis was used to answer the fourth research question. Pearson Product Moment Correlation 
was used to find the relationships between the variables measured on an interval level (i.e. computer perceptions and computer competence). Spearman's rank correlation was used to find the relationships between the interval dependent variable and nominal and ordinal independent variables (i.e. demographic variables).

\section{Results}

This section reports the findings of the study, beginning with the demographic information of the teacher respondents before dealing with each research question. The second section presents descriptive statistics about teachers' application of ICT in their teaching. The third section also uses descriptive statistics to analyze factors influencing teachers to use ICT in their teaching.

\section{Demographic Information of Teachers}

The demographic information of teachers included gender, age, teaching experience, computer experience, and frequency of teachers' use of computer as shown in Table 1. Of the 231 teachers, $66.2 \%$ were males and $33.8 \%$ were females. From the table majority of the respondents $(25.5 \%)$ had 11-15 years of teaching experience. Also, about one third of the respondents (35.9\%) reported using computers daily. The result is consistent with (Lau \& Sim, 2008) who found teachers using ICT either daily or weekly for teaching and learning support.

Table1. Demographic Information of Respondents

\begin{tabular}{llcc}
\hline Variable & Category & Frequency & Percent \\
Gender & Male & 153 & 66.2 \\
Age & Female & 78 & 33.8 \\
& $20-29$ & 26 & 11.3 \\
& $30-39$ & 85 & 36.8 \\
& $40-49$ & 79 & 34.2 \\
Teaching Experience & $50-59$ & 39 & 16.9 \\
& 60 and above & 2 & .9 \\
& $1-5$ & 48 & 20.8 \\
& $6-10$ & 43 & 18.6 \\
Computer Experience & $11-15$ & 59 & 25.5 \\
& $16-20$ & 46 & 19.9 \\
& Over 20 & 35 & 15.2 \\
& Not at all & 11 & 4.8 \\
& Less than 1 & 22 & 9.5 \\
& $1-3$ & 51 & 22.1 \\
& $4-6$ & 76 & 32.9 \\
& $7-10$ & 44 & 19.0 \\
& Over 10 & 27 & 11.7 \\
\hline
\end{tabular}




\begin{tabular}{llcc}
\hline Computer Usage & Not at all & 12 & 5.2 \\
& Occasionally & 66 & 28.6 \\
Monthly & 12 & 5.2 \\
& Weekly & 58 & 25.1 \\
& Daily & 83 & 35.9 \\
\hline
\end{tabular}

\section{Research Question 1: What are teachers' perceptions of the application of ICT in teaching?}

Respondents were asked to indicate on a five-point scale ranging from strongly disagree (1) to strongly agree (5) their views on the transformative role of ICT in their teaching and learning situation. As shown in Table 2, the majority of the respondents perceived that ICT can offer opportunities to teachers for obtaining educational resources from the internet to enrich course content (Mean $=4.75$ ) and also can improve teaching and learning processes (Mean $=4.63$ ). The majority of the respondents also agreed or strongly agreed that ICT can enhance students' participation and feedback to teachers (90.9\%) and improve students' collaboration (90.4\%). On the other hand, ICT can improve students' language writing skills $(76.2 \%$, mean $=3.94$ ) was perceived as the lowest. In general teachers' perceptions of the application of ICT in teaching and learning environment were positive.

Table 2. Descriptive Statistics of Teachers' Perception of the Application of ICT in Teaching

\begin{tabular}{lccccccc}
\hline Variables & $\begin{array}{c}\text { SD } \\
(\%)\end{array}$ & $\begin{array}{c}\text { D } \\
(\%)\end{array}$ & $\begin{array}{c}\text { N } \\
(\%)\end{array}$ & $\begin{array}{c}\text { A } \\
(\%)\end{array}$ & $\begin{array}{c}\text { SA } \\
(\%)\end{array}$ & Mean & StDev \\
\hline $\begin{array}{l}\text { 1. ICT can improve teaching and } \\
\text { learning processes }\end{array}$ & 0.4 & 0.9 & 2.6 & 27.7 & 68.4 & 4.63 & 0.63 \\
$\begin{array}{l}\text { 2. ICT can enhance students' critical } \\
\text { thinking skills. }\end{array}$ & 2.2 & 3.9 & 6.9 & 48.1 & 39.0 & 4.18 & 0.88 \\
$\begin{array}{l}\text { 3. ICT can enhance students' } \\
\text { participation, and feedback to teachers }\end{array}$ & 0.0 & 1.7 & 7.4 & 46.3 & 44.6 & 4.34 & 0.69 \\
$\begin{array}{l}\text { 4. ICT can enhance collaboration among } \\
\text { students }\end{array}$ & 0.0 & 1.3 & 8.2 & 59.7 & 30.7 & 4.20 & 0.64 \\
$\begin{array}{l}\text { 5. ICT can enhance teacher and student } \\
\text { interaction }\end{array}$ & 0.4 & 1.3 & 8.7 & 49.4 & 40.3 & 4.28 & 0.71 \\
$\begin{array}{l}\text { 6. Internet can offer opportunities to } \\
\text { teachers for obtaining educational } \\
\text { resources to improve on course content }\end{array}$ & 0.0 & 0.0 & 3.9 & 17.3 & 78.8 & 4.75 & 0.52 \\
$\begin{array}{l}\text { 7. ICT tends to increase students' } \\
\text { learning motivation }\end{array}$ & 1.7 & 3.5 & 7.8 & 40.3 & 46.8 & 4.27 & 0.88 \\
$\begin{array}{l}\text { 8. ICT can enhance students' language } \\
\text { writing skills (e.g. grammar, spelling, } \\
\text { punctuation, etc) }\end{array}$ & 2.2 & 12. & 9.5 & 42.0 & 34.2 & 3.94 & 1.06 \\
\hline
\end{tabular}

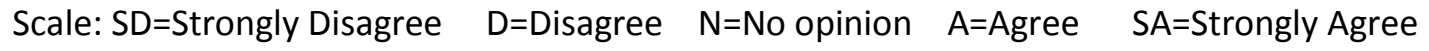




\section{Research Question 2: What are teachers' perceived skills in ICT?}

Teachers' were asked to rate their ICT skills on a four-point Likert-type scale ranging from "Cannot use/none (1)" to "High (4)".

Table 3. Descriptive Statistics of Teachers' Perceived ICT Skills

\begin{tabular}{|c|c|c|c|c|c|c|}
\hline ICT skills & $\begin{array}{c}\text { Cannot } \\
\text { use }\end{array}$ & Low & Moderate & High & Mean & StDev \\
\hline $\begin{array}{l}\text { Word processor } \\
\text { (e.g.Microsoft word) }\end{array}$ & 7.4 & 15.6 & 44.6 & 32.5 & 3.02 & .882 \\
\hline $\begin{array}{l}\text { Spreadsheet (e.g. } \\
\text { Microsoft Excel) }\end{array}$ & 15.6 & 29.0 & 38.1 & 17.3 & 2.57 & .952 \\
\hline $\begin{array}{l}\text { Presentation (e.g. } \\
\text { Microsoft PowerPoint) }\end{array}$ & 23.4 & 24.2 & 29.9 & 22.5 & 2.52 & 1.083 \\
\hline $\begin{array}{l}\text { Database (e.g. Microsoft } \\
\text { Access) }\end{array}$ & 32.9 & 33.3 & 24.2 & 9.5 & 2.10 & .972 \\
\hline $\begin{array}{l}\text { Search engines (e.g. } \\
\text { Internet/WWW) }\end{array}$ & 14.7 & 15.6 & 32.9 & 36.8 & 2.92 & 1.054 \\
\hline $\begin{array}{l}\text { Communication (e.g. } \\
\text { Email) }\end{array}$ & 10.0 & 17.3 & 34.2 & 38.5 & 3.01 & .980 \\
\hline
\end{tabular}

Cronbach alpha $=.924$

As shown in Table 3, majority of the respondents were moderately competent in word processor $(77.2 \%$, mean $=3.02)$ and communication $(72.7 \%$, mean $=3.01)$. On the other hand, majority of the respondents perceived their skill in database as "low" or "cannot use" $(66.2 \%$, mean $=2.10)$. The result is in agreement with Jegede et al. (2007) and Lau and Sim (2008) who found teachers to be more proficient in word processing than the other applications.

\section{Research Question 3: What is the extent of teachers' integration of ICT into teaching and} learning processes?

Respondents were asked to respond to the extent to which they integrate ICT into their teaching on a four-point Likert-type scale ranging from "never" (1) to "Almost Always" (4). The results of the study showed that computer was almost always used by teachers (mean $=1.84$, see Table 4 ) and this was followed by the Internet (mean $=1.80$ ) as indicated in Table 3 . The least used hardware by teachers was the overhead projector (mean $=1.38$ ). The overall mean score was 1.63 and the overall standard deviation was 0.82 signifying low use of hardware tools by teachers in their teaching. The reasons for low use of these hardware tools could be attributed to lack of access to equipment in classroom, lack of teachers' training skills in the use of the equipment. This result is in agreement with SITES M1 study which found that lack of computer literacy among teachers, lack of training with regards to integration of ICT into teaching and absence of a properly 
developed computer skills curriculum were barriers to teachers' application of the technology (Howie, Muller, \& Paterson, 2005).

Table 4. Descriptive Statistics of Hardware Used by Teachers

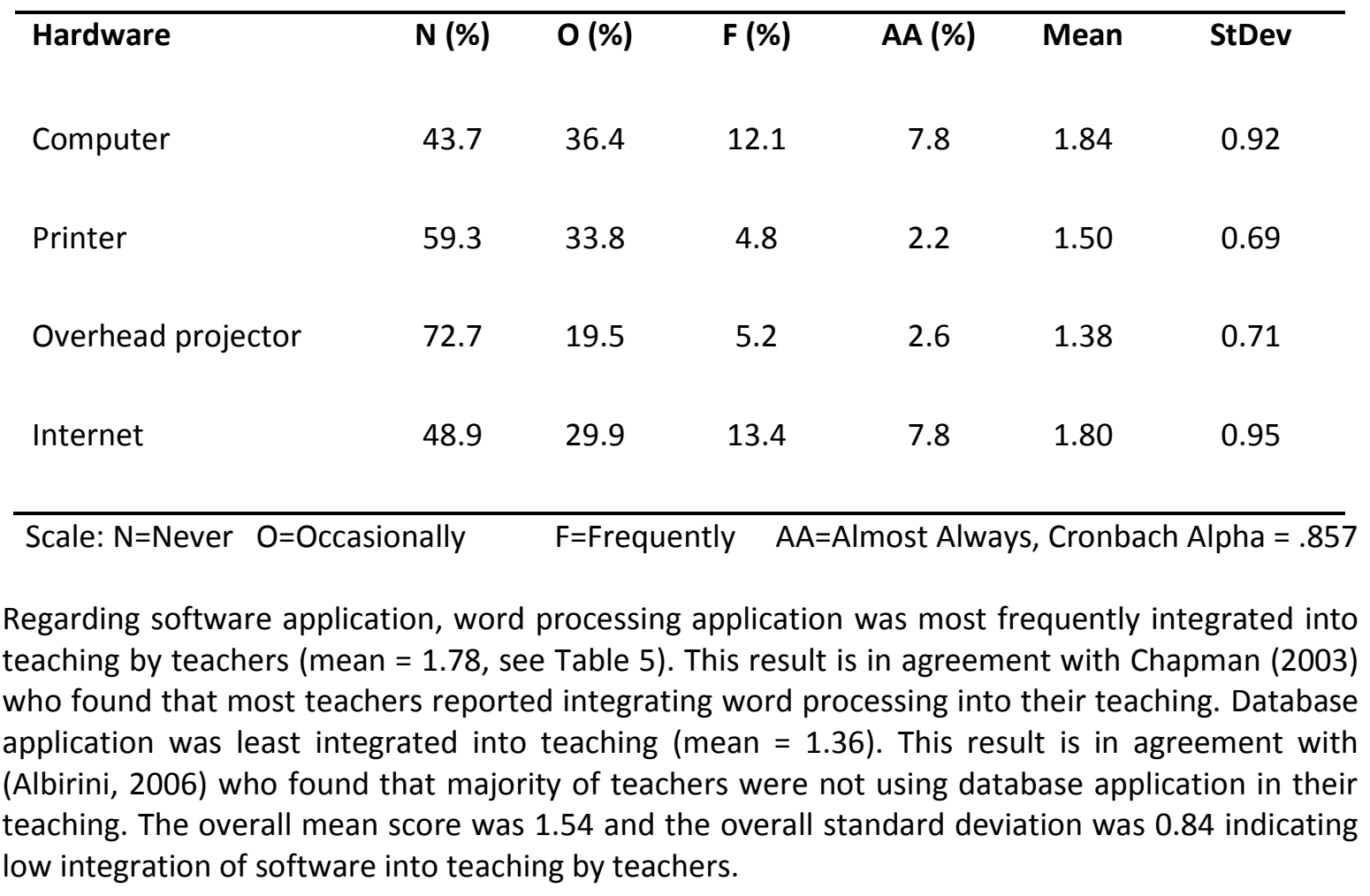

Table 5. Descriptive Statistics of Software Used by Teachers

\begin{tabular}{|c|c|c|c|c|c|c|}
\hline Software & $\mathbf{N}(\%)$ & $\mathrm{O}(\%)$ & $F(\%)$ & AA (\%) & Mean & SD \\
\hline for word processing & 52.8 & 26.0 & 11.7 & 9.5 & 1.78 & 0.99 \\
\hline for Spreadsheet & 63.2 & 21.6 & 9.5 & 5.6 & 1.58 & 0.88 \\
\hline for presentation & 61.9 & 25.5 & 9.1 & 3.5 & 1.54 & 0.80 \\
\hline for Database & 76.2 & 15.2 & 5.2 & 3.5 & 1.36 & 0.74 \\
\hline $\begin{array}{l}\text { for instructional } \\
\text { software }\end{array}$ & 68.4 & 21.2 & 6.5 & 3.9 & 1.46 & 0.78 \\
\hline
\end{tabular}

Scale: $\mathrm{N}=$ Never $\quad \mathrm{O}=$ Occasionally $\quad \mathrm{F}=$ Frequently $\quad \mathrm{AA}=$ Almost Always, Cronbach alpha $=.924$ 
Respondents were also asked to what extent they incorporated ICT into their teaching. The results of the study revealed that ICT was most frequently used to assess students' learning through test or quizzes (mean $=1.68$ ) and second was used to give instructions to students in classroom (mean $=1.65$ ). Using computers to send feedback to students as well as communicating with students were least used $($ mean $=1.57$; mean $=1.58$, see Table 6$)$. These observations are clear evidence that the introduction of ICT in teaching and learning has not transformed educational delivery in second-cycle schools in Ghana implying that teachers have not shifted from teacher-centered teaching to student-centered learning despite government effort to support teachers with training in ICT integration into teaching.

Table 6. Frequency Percentages on Teaching Activity

\begin{tabular}{|c|c|c|c|c|c|c|}
\hline Teaching activity & $\mathbf{N}(\%)$ & $\mathrm{O}(\%)$ & F (\%) & AA (\%) & Mean & StDev \\
\hline Giving class instructions & 51.1 & 34.6 & 12.6 & 1.7 & 1.65 & 0.77 \\
\hline $\begin{array}{l}\text { Communicating with } \\
\text { students }\end{array}$ & 56.3 & 32.0 & 9.5 & 2.2 & 1.58 & 0.75 \\
\hline $\begin{array}{l}\text { Organizing class } \\
\text { discussion, } \\
\text { demonstrations and } \\
\text { presentations }\end{array}$ & 58.0 & 26.8 & 9.5 & 5.6 & 1.63 & 0.88 \\
\hline $\begin{array}{l}\text { Assessing students' } \\
\text { learning through } \\
\text { tests/quizzes }\end{array}$ & 51.5 & 32.5 & 12.6 & 3.5 & 1.68 & 0.82 \\
\hline $\begin{array}{l}\text { Sending feedback to } \\
\text { students }\end{array}$ & 55.4 & 34.2 & 8.7 & 1.7 & 1.57 & 0.72 \\
\hline $\begin{array}{l}\text { Supporting collaboration } \\
\text { among students }\end{array}$ & 52.8 & 33.8 & 10.8 & 2.6 & 1.63 & 0.78 \\
\hline
\end{tabular}

Scale: $\mathrm{N}=$ Never $\mathrm{O}=$ Occasionally $\quad \mathrm{F}=$ Frequently $\quad \mathrm{AA}=\mathrm{Almost}$ Always, Cronbach $\alpha=0.92$

\section{Research Question 4: What is the relationship between teachers' actual use of ICT and their computer perceptions, computer competence and demographics (such as age, teaching experience and computer experience)?}

As shown in Table 7, there was a substantial positive correlation between teachers' competences and ICT use $(r=.68, p<.01)$. Further analysis showed moderate positive relationship between computer experience and ICT use $(r=.49, p<.01)$. The correlation between perception and ICT use was positive and low but not statistically significant $(r=.09, p>.01)$. Finally, the study revealed inverse correlation between ICT use, age and teaching experience. 
Table 7. Summary of Correlation Matrix of ICT Use and Independent Variables

\begin{tabular}{lllllll}
\hline Variable & ICT use & $\begin{array}{l}\text { Comp } \\
\text { perception }\end{array}$ & $\begin{array}{l}\text { Comp. } \\
\text { competence }\end{array}$ & Age & $\begin{array}{l}\text { Teaching } \\
\text { experience }\end{array}$ & $\begin{array}{l}\text { Computer } \\
\text { experience }\end{array}$ \\
ICT use & 1.00 & & & & \\
Comp. perception & .09 & 1.00 & & & \\
Comp. competence & $.68^{* *}$ & $.22^{* *}$ & 1.00 & & \\
Age & $-.23^{* *}$ & $.11^{* *}$ & $-.28^{* *}$ & 1.00 & \\
Teaching experience & $-.31^{* *}$ & $.20^{* *}$ & $-.34^{* *}$ & $.69^{* *}$ & 1.00 & \\
Computer experience & $.49^{* *}$ & $.19^{* *}$ & $.59^{* *}$ & $-.25^{* *}$ & $-.21^{* *}$ & 1.00 \\
\hline **. Correlation is significant at the 0.01 level (2-tailed) & & &
\end{tabular}

\section{Discussion and Conclusion}

The findings of this study revealed that majority of teachers were moderately competent in word processing. The result is in agreement with Jegede et al. (2007) and Lau and Sim (2008) who found teachers to be more proficient in word processing than the other computer applications. This means that teachers have not got mastery of ICT skills in many applications. Evidence reveals that teachers' mastery in ICT skills is critical to successful integration of ICT into teaching (Rosenfield \& Martinez-Pons, 2005).

In this study the extent to which teachers integrate ICT into their teaching and learning processes was explored. It was found that the hardware frequently used by teachers was the computer, and the software mostly used for integration was word processing. This finding is consistent with what Becker, Ravitz, and Wong (1999) found that word processing software, CD-ROM reference software, and World Wide Web browsing software were the most commonly used applications by teachers regardless of the subject they taught. However, the result of the study revealed that both hardware and software were lowly integrated into teaching and learning processes by teachers.

This result is in agreement with SITES M1 study which found that lack of computer literacy among teachers, lack of training with regards to integration of ICT into teaching and absence of a properly developed computer skills curriculum were barriers to teachers' application of the technology (Howie, Muller \& Paterson, 2005).

The study also demonstrated that teachers mainly used computers for students' assessments and for class instructions. The least used of technology by teachers in classrooms were communication with students and providing feedback to students. The results of the study suggested that the general integration of ICT in teaching activities was low. These results of the study are clear evidence that the introduction of ICT in teaching and learning has not transformed educational delivery in second-cycle schools in Ghana implying that teachers have not shifted from teacher- 
centered teaching to student-centered learning. The reasons for the low use of these hardware and software could be attributed to lack of access to technological resources in classroom and lack of teachers' training skills in the use of the equipment.

The findings revealed positive correlation between ICT use and competences $(r=.68, p<.01)$. This result is consistent with Sorgo, Verckovnik and Kocijancic (2010) who found high correlation between frequency of use of ICT, perceived value and teachers' competence in use of ICT among science teachers. They concluded that teachers' competence and confidence were predictors of using ICT in teaching. The data analysis also showed positive relationship between computer experience and ICT use $(r=.49, p<.01)$. Petrogiannis (2010) examined 396 kindergarten teachers' perceived preparedness for computer use in the preschool classes and the potential difference between computer experienced and non- experienced teachers. They concluded that computer experienced teachers were more ready to use ICT in their classes than non- experienced teachers.

Further, the analysis revealed that teachers' perceptions with regards to the use of ICT were positive and low but not statistically significant. This revelation casts doubts on other findings which have reported that teachers' actual ICT use related to their perceptions (Altun, Alev \& Yigit, 2009; Keengwe \& Onchwari, 2008; Lau \& Sim, 2008). This finding, on the other hand, is in confirmation with Eugene (2006) who explored the effect of teachers' beliefs and attitudes towards the use of ICT in classrooms. The study revealed that there was inconsistency between teachers' beliefs and their actual use of technology in classroom. Teachers' beliefs and teaching practices were found not to match. The inconsistency between teachers' actual use of ICT and perception can be attributed to inadequate supply of ICT resources, lack of access to the right kinds of technology, inadequate ICT pedagogical training and insufficient administrative support.

Finally, the study revealed inverse correlation between ICT use, age and teaching experience. This finding supports van Braak et al. (2004), Bebell, Russell, \& O'Dwyer (2004), and Inan and Lowther (2010) assertions that ICT use falls with age and teaching experience and that younger teachers integrated ICT into their teaching more than veteran teachers. Some researchers have attributed veterans' use of computers to limited computer competence (Bingimals, 2009), confidence (Robinson, 2003; Snoeyink \& Ertmer, 2001) and preparedness to use ICT in their classes (Inan \& Lowther, 2010).

From the results of the study, it is recommended that teachers be given sufficient training on how to use ICT into teaching and learning processes to acquire the requisite knowledge and skills in integrating the technology in classrooms. This will provide opportunities for teachers to support student-centered learning. According to Russell, Bebell, O'Dwyer and O'Connor (2003), teachers should be trained on specific instructional use of technology instead of general use of computers. In addition, training should be provided on the use of ICT software other than simple word processing.

From the findings, it seems teachers are either trained specifically on the use of word processing or experts are not recruited to train teachers well. In addition professional development program be provided continuously for teachers to update their ICT knowledge and skills. Also, courses such as computer supported learning, ICTs and design of teaching materials should be introduced in 
initial teachers' training schools to increase teacher trainees' level of confidence and perceptions of the use of ICT.

Finally, teachers should be provided with adequate technological resources, technical support and administrative support to encourage them to successfully use ICT in classrooms. Yee (2000) believes that a leader who implements technology plans and also shares a common vision with the teachers stimulate them to use technology in their lessons.

\section{Limitations and Future Research}

This study was limited to only teachers in second-cycle institutions. The other limitation was the self-report scales were used to measure variables for analysis. This could affect the result of the study. For future study, similar quantitative research can be carried out in basic schools, initial teachers' training schools, and tertiary institutions. Further research can also be carried out to examine the correlation between ICT use and administrative support, peer-to-peer support and important students' characteristics.

\section{References}

Albirini, A. (2006). An exploration of the factors associated with the attitudes of high school EFL teachers in Syria toward information and communication technology (Unpublished dissertation). Ohio State University.

Altun, T., Alev, N., \& Yigit, N. (2009). An investigation of pre-service science teachers' views about their technical and pedagogical skills in the use of ICT. Proceedings of the $9^{\text {th }}$ International Educational Technology Conference (pp.515-521). Ankara: Hacettepe University.

Bebell, D., Russell, M., \& O’Dwyer, L. (2004). Measuring teachers' technology uses: Why multiple measures are more revealing. Journal of Research on Technology in Education, 37(1), 45-63.

Becta (2008) Harnessing technology: Schools survey 2008. Retrieved 20 October 2011 from http://emergingtechnologies.becta.org.uk/uploaddir/downloads/page_documents/re earch/ht_schools_survey08_analysis.pdf. [Accessed 20th October 2011]

Becker, H. J., Ravitz, J. L., and Wong, Y. T. (1999). Teachers and teacher-directed student use of computers and software. Irvine, California: University of California Centre for Research on Information Technology and Organizations. Retrieved 9 January 2012 from http://www. crito.uci.edu/tlc/findings/computeruse/html/startpage.htm

Bingimlas, K. (2009). Barriers to successful integration of ICT in teaching and learning environment: A review of the literature. Eurasia Journal of Mathematics, Science and Technology Education, 5(3), 235-245.

Chapman, B. (2003). An assessment of business teacher educators' adoption of computer technology (Unpublished dissertation). Virginia Polytechnic Institute and State University. 
Drent, M. \& Meelissen, M. (2008) .Which factors obstruct or stimulate teacher educators to use ICT innovatively? Computers \& Education, 51(1), 187-199.

Eugene, J. (2006). How teachers integrate technology and their beliefs about learning: Is there a connection? Journal of Technology and Teacher Education, 14(3), 581-597.

EU Schoolnet. (2010). Summary: Netbook pre-pilot evaluation for teachers. Availabe at: http://www.eun.org/web

Gulbahar, Y. (2008). ICT usage in higher education: A case study on preservice teachers and instructors. Turkish Online Journal of Educational Technology, 7(1). Available at: http://www.tojet.net/articles/v7i1/713.pdf

Hew, K. F. \& Brush, T. (2007). Integrating technology into K-12 teaching and learning: current knowledge gaps and recommendations for future research. Educational Technology Research \& Development, 55, 223-253.

Howie, S. J., Muller, A., \& Paterson, A. (2005). Information and communication technologies in South African secondary schools. Pretoria: JISRC

Huang, H. M. \& Liaw, S. S. (2005). Exploring users' attitudes and intentions toward the Web as a survey tool. Computers in Human Behavior, 21(5), 729-743.

Inan, F. A. \& Lowther, D. L. (2010). Factors affecting technology integration in K-12 classrooms: A path model. Educational Technology Research \& Development, 58(2), 137-154.

Jegede, P. O., Odusola, O. D, Ilori, M. O. (2007). Relationships between ICT competence and attitude among Nigerian tertiary institution Lecturers. Educational Research and Review, 2(7), 172-175.

Keengwe, J. \& Onchwari, G. (2008). Computer technology integration and student learning: Barriers and promise, Journal of Science Education and Technology, 17, 560-565.

Kline, R. B. (2005). Principles and practice of structural equation modeling ( $2^{\text {nd }}$ edition). New York: Guildford.

Korte, W. B. \& Husing, T. (2007). Benchmarking access and use of ICT in European schools 2006: Results from head teacher and a classroom surveys in 27 European countries. E-learning Papers, 29(10), 1-6.

Lau, C. T. \& Sim, C. H. (2008). Exploring the extent of ICT adoption among secondary teachers in Malaysia. International Journal of Computing and IT research, 2(2), 19-36.

Petrogiannis, K. (2010). The relationship between perceived preparedness for computer use and other psychological constructs among kindergarten teachers with and without computer experience in Greece. Journal of Information Technology Impact, 10(2), 99-110.

Rahimi, M. \& Yadollahi, S. (2011). ICT use in EFL classes: A focus on EFL teachers' characteristics. World Journal of English Language, 1(2), 17-29

Robinson, W. I. (2003). External and internal factors which predict teachers' computer usage in K12 classrooms. Detroit, MI: Wayne State University. 
Rosenfeld, B. \& Martinez-Pons, M. (2005). Promoting classroom technology use. The Quarterly Review of Distance Education, 6(2), 145-153.

Rozell, E. J. \& Gardner, W. L. (1999). Computer-related success and failure: a longitudinal field study of the factors influencing computer-related performance. Computers in Human Behavior, 15(1), 1-10.

Russell, M., Bebell, D., O'Dwyer, L. and O'Connor, K. (2003). Examining teacher technology use: Implications for preservice and inservice teacher preparation. Journal of Teacher Education, 54(4), 297-310.

Simonson, M. (2004). Technology use of Hispanic bilingual teachers: A function of their beliefs, attitudes and perceptions on peer technology use in the classroom. Journal of Instructional Technology, 31(3), 257-266.

Snoeyink, R. \& Ertmer, P. A. (2001). Thrust into technology: How veteran teachers respond. Journal of Educational Technology Systems, 30(1), 85-111.

Sorgo, A., Verckovnik, T., \& Kocijancic, S. (2010). Information and communication technologies (ICT) in biology teaching in Slovenian secondary schools. Eurasia Journal of Mathematics, Science and Technology Education, 6, 37-46.

Teo, T. (2008). Pre-service teachers' attitudes towards computer use: A Singapore survey. Australasian Journal of Educational Technology, 24(4), 413-424.

van Braak, J., Tondeur, J., \& Valcke, M. (2004). Explaining different types of computer use among primary school teachers. European Journal of Psychology of Education, 19, 407-422.

Woodrow, J. E. (1992). The influence of programming training on the computer literacy and attitudes of pre-service teachers. Journal of Research on Computing in Education, 25(2), 200-219.

Yee, D. L. (2000). Images of school principals' information and communication technology leadership. Technology, Pedagogy and Education, 9(3), 287-302.

Correspondence: Charles Buabeng-Andoh, Ph.D. Candidate, Pentecost University College, Accra, Ghana 